\title{
A Critical and Semiotic Approach to the Wonderful, Horrible Life Cycle of the Kony 2012 Viral Video
}

\author{
Fernando Andacht \\ University of Ottawa, Ottawa, Canada, fandacht@uottawa.ca, \\ http://www.communication.uottawa.ca/eng/faculty/andacht.html
}

\begin{abstract}
The article studies from a Peircean semiotic perspective the critical response to a webdoc made by the Invisible Children NGO and uploaded to YouTube and other social media in March 2012. It aimed at helping to capture the leader of the Lord's Resistance Army (LRA), a group responsible for kidnapping children to make them soldiers that was allegedly active in Uganda. The remarkable contrast between the fastest-growing, largest audience gathered by a video in the history of internet with its fierce 'backlash', a number of disparaging comments in print and online media makes the Kony 2012 video uploaded on YouTube an interesting case study. The article considers part of the criticism as a new-fangled version of what early functionalism called "the narcotizing dysfunction" of media, Lazarsfeld and Merton's (1948) account of the apathy of the media audience despite an increase in their intake of information. The paper argues that the main rhetorical strategy of this Internet campaign is similar to that used in popular factuality programming (e.g. reality shows and docudramas), namely, the prevalence of indexical signs to arouse strong emotions. Part of its proclaimed failure as a humanitarian campaign according to its numerous critics is due, in the author's view, to the reductionistic/dualistic approach of many critics to the video's audience.
\end{abstract}

Keywords: Kony 2012, Critical Response, Early Functionalism, Semiotic, Dualism, Invisible Children NGO

Acknowledgement: I would like to express my gratitude for the Social Sciences and Humanities Research Council (SSHRC) grant that has made possible my study of the representation of reality in the past three years.

\section{Introduction: A Controversial Web-Based Humanitarian Campaign}

The aim of this article is to contribute to develop a better, more potent critical theory of visual media by using as a case study the fierce debate around an intensely criticized and heavily viewed web-based documentary Kony 2012 made by the American NGO Invisible Children (henceforth IC) in March 2012. A central question for this study is: how is the vast audience of this webdoc construed by this critical discourse? Is it possible that the hoary dichotomy of passive (or helpless) audience vs. active (or powerful/direct) media still plays a central role in the field of visual communication, when media have changed so much since the late $19^{\text {th }}$ century when this division was first formulated in communication studies? Now that the numerous, interactive Social Networking Sites (SNS) of the internet are an affordance that promotes a horizontal type of communication instead of the top-to-bottom kind of the past, has this analytical opposition reached its expiry date?

The strong tension inherent in the subject matter of this article can be expressed in the words that I borrowed for its title from that of a documentary on a controversial filmmaker, namely, Ray Müller's The Wonderful, Horrible Life of Leni Riefenstahl (1993). Ironically, what could have been hailed as the most successful humanitarian campaign ever made in the age of social media became the target of fierce criticism and of pungent denunciation online and in print media (newspapers and journals), the so-called "Kony 2012 backlash." Much of this criticism is justified: there are factual and ideological flaws in the audiovisual narrative on human rights violations told and shown in the IC webdoc. Let us go to the video content now. In an allusion to the publicized "Arab spring," and its alleged reliance on Facebook, the voiceover narrative of Kony 2012 describes epically how vital the globalized realm of social media has become and how it can help to right a long-lasting abuse of human rights in Central Afri- 
ca. It features as its heroes three young American men who ten years ago went there and learned about the brutal attacks of Joseph Kony and his irregular troops, the Lord's Revolution Army (LRA). This encounter is personified through one of its victims, a Ugandan boy named Jacob Achaye, who escaped from LRA military slavery. His touching participation as an eyewitness of the brutality is a highlight of Kony 2012. Co-founder of IC Jason Russell is the protagonist and narrator of the film; he promises the former child soldier to stop the LRA's leader. In fact, STOP KONY became the slogan of the 2012 campaign. Viewers are told how they can make a difference by contributing financially to put an end to the evil deeds of a man who has been playing havoc with the region for over two decades. A list of frightening facts follows: 30,000 abducted children; girls become sex slaves, boys are told to kill their own parents. To legitimize this information, we watch the head prosecutor of the International Criminal Court, who explains why Kony's heinous crimes have placed him at the top of the ICC's ranking of the world's worst criminals. Then the narrator claims that the main obstacle for accomplishing this task is the world's unawareness of the evil deeds of the LRA's leader. The goal of IC's campaign is a radical 'agenda setting' strategy: to influence public opinion, so that it exerts pressure on the US government to arrest Kony. A David vs. Goliath approach is presented whereby young people's idealism and small money contributions can make the world better by helping the victims of the LRA. The progress of the IC campaigns is shown through the quick growth of their Facebook membership. A decision of the US Congress to send military aid to Central Africa to help capture Kony signed by Barack Obama is exhibited as a victory of the NGO. Then a clip shows us why Kony is still at large. The solution offered is to make him an infamous celebrity: by plastering Kony's face and name all over the world, it claims, the people will know and demand that the US government maintains its military aid to arrest him. By making Kony "famous," says Russell, he will no longer be "invisible," he will become "a household name." To do that, a list of celebrities and another of policy makers are displayed: they must be persuaded to join the IC campaign and make Kony famous. It asks viewers to buy "the action kit" with bracelets and posters. The climax of this campaign is announced: the "Cover the Night" event, on April $20^{\text {th }}, 2012$, when posters of Kony 2012 will be put on walls and hung from buildings throughout North America, "demanding justice on every corner." The film ends with a written message inviting people "to share this movie online. It is free." Now, I will consider the elements that turned what seemed a very successful Internet humanitarian campaign into a controversial one. Just as it happened to German artist and pioneer documentary director Leni Riefenstahl, the high praise of critics for the creativity of her documentaries was tarnished by the subject matter of her two classic films and by the dazzling aesthetic and technological treatment of it: the glorification of $\mathrm{Na}$ zism and of its infamous leader.

In the case of Kony 2012, there are many reasons for the fierce critical response to it. The video and its makers, particularly Jason Russell, the man who is portrayed as the ideologue of this humanitarian campaign, became the target of a critical demolition. Below I analyze some aspects of this criticism, because I argue that it inadvertently reproduces what is most harshly attacked in the video: the excessive simplification of a highly complex situation, i.e., the humanitarian crisis caused by irregular and regular troops in Central and Eastern Africa, and the US military solution recommended by IC to solve this problem. ${ }^{1}$ Ironically, the nature of the reception process and the kind of audience of Kony 2012 described in the critical discourse stem from strategies of oversimplification and ideological distortion that are akin to those denounced by the critics of the video's narrative, ideology and visual rhetoric. To account for this peculiar situation, I use an expression that designates a fallacious argument, when it deliberately misrepresents the adversary's position: a straw man. According to most critics of Kony 2012, the video's representation of the African warlord Joseph Kony, whom the IC campaign accuses of horrific crimes involving the kidnapping of thousands of children

\footnotetext{
${ }^{1}$ For a detailed political and historical context of this humanitarian crisis see Finnegan $(2013,140-145)$ and the useful report by Brown et al. (2012).
} 
and the mass murder of the civilian population of Uganda for the past two decades, ${ }^{2}$ is a grossly oversimplified and intentionally distorted account of the actual situation in that part of Africa. Although the man accused of those appalling misdeeds is not said to be innocent by the critics, they claim that the way in which he is portrayed in Kony 2012 has made of him what I propose to call a visual straw man, i.e., a specious misrepresentation of a complex situation, one that involves many more villains and geopolitical factors than the colorful Manichean audiovisual story so persuasively told by IC. The critical construal of the audience of this video also creates a straw man: an oversimplified, distorted, and disparaging representation of a far more intricate issue, namely, the reception process or "system of response" (Braga 2006) of Kony 2012.

I do not intend to add any further objection to the many that have already been justly denounced by journalists, bloggers, and scholars from Africa and North America. Neither will I attempt to bring to light some as yet unmentioned virtues of Kony 2012 to add to the few that the much smaller group of positive reviewers of this campaign of IC has written or blogged about. I intend to use the video material and the abundant criticism that it generated to revisit another classical notion from communication theory besides the active vs. passive dichotomy mentioned above: the "narcotizing dysfunction" of mass media (Lazarsfeld and Merton 1948) and some recent contributions to media reception (Mosco and Kaye 2000; Braga 2006). They will be discussed in relation to central notions of semiotic theory, namely, Peirce's triadic model, and specifically the epistemic value of iconic signs together with indexical signs. The analytical relevance of semiotic as a communication theory has been cogently explained by Santaella and Nöth (2004).

In 1868, Peirce stated that an inquiry must begin by acknowledging our own prejudices, those which cannot "be dispelled by a maxim for they are things which it does not occur to us can be questioned" (CP 5.265). ${ }^{3}$ In my case, the prejudice is the value of Peircean triadic semiotic theory, which I have adopted as the epistemological and methodological framework. From such perspective, I will analyze the critiques generated by Kony 2012, whose peculiar goal was to make a criminal world-famous, particularly in North America, so as to stop the LRA's evil deeds in Central Africa. The specific present whereabouts of Kony's army was one of the contentious aspects of the campaign according to its critics.

Based on an epistemological critique of dualism that is crucial to triadic semiotic, I claim there is a dualistic assumption underlying many of the critiques of Kony 2012, both journalistic and academic. Thus, the reductionism inherent in the traditional opposition between active and passive, when it comes to considering media audience behavior, could benefit from the principle of logical continuity or synechism, which Peirce proposes as the nondualistic basis of any inquiry, and a fortiori, of the study of sign phenomena, which are essential for any kind of communication be it personal or public. The contribution I hope to make to critical visual theory in the age of Facebook, YouTube and Instagram is that media criticism based on dualism, as it is the case with many of the examples drawn from the critical "backlash" that arose in the wake of the popularity of Kony 2012, ends up reproducing the same kind of oversimplifying reductionism of which these critics accuse this video. This state of affairs could also be explained as the upshot of the Cartesian mistrust of images and the invidious praise of verbal signs: iconic signs pitted against symbolic signs in semiotic terms. To deal with this epistemological prejudice, I use the exegesis of Peircean scholar Ransdell (1979, 1997; Andacht 2003), who proposed a semiotically-based critical theory of images that posits the existence of the "curmudgeon spirit," a Cartesian-inspired suspicion of the existence of any rational value in images in contrast with the reliable rational value of verbal signs. A semiotic critical theory of visual materials in the age of SNS, which is my own take on this issue

2 The dates, the exact location as well as the present military force of the rebel troops guided by J. Kony, the Lord's Resistance Army, were all unanimously contested by a number of critics in what came to be known as "the backlash" to the Kony 2012 video in the media.

${ }^{3}$ References to The Collected Papers of Charles S. Peirce are made in the usual way: "CP x.xxx," which refers to the volume and to the paragraph of that edition, and to the two-volume edition of The Essential Peirce. Selected Philosophical Writings also "EP: x," which refers to the first and second volume, followed by the page. 
- is also bound to have its blind spots. Hopefully, they will emerge in further critical studies of the visual realm.

\section{The Critiques of the Kony 2012 Webdoc Seen in a Semiotic Light}

What could go wrong when an NGO decides to make a video and upload it on YouTube to denounce vicious crimes committed against children and the civilian population in East Africa, misdeeds such as the kidnapping of boys to make them child soldiers of the infamous Lord's Resistance Army led by Joseph Kony, the turning of girls into sex slaves and innumerable atrocities against the population? If there ever was a group that deserved humanitarian aid and to become the object of "the politics of pity" (Boltanski 2004), ${ }^{4}$ which must always struggle to find space in the media since "the central problem confronted by a politics of pity is actually the excess of unfortunates" (155), the people described above fully merits the vast media attention that the video Kony 2012 gained in record time. ${ }^{5}$

At the core of Peirce's semiotic model there is a logical relationship of great generality that accounts for its explanatory power of meaning phenomena, cultural and natural. That is why the triadic sign model can be useful as an analytical tool of critical visual theory: "A sign, or representamen, is something which stands to somebody for something in some respect or capacity. It addresses somebody, that is, creates in the mind of that person an equivalent sign, or perhaps a more developed sign. That sign which it creates I call the interpretant of the first sign" (CP 2.228, c. 1897).

In what follows, the sign relationship is used to account for the main objections raised to the video by the critics. Each node of the sign triad serves to examine the three areas of contention that were the target of heavy criticism during the Kony 2012 backlash in March 2012: a) the facts that make up the narrative (i.e., the "something" represented or semiotic Object); b) the formal, aesthetic strategy of the story told in the video (= the Representamen/sign); c) the meaning effects generated by the video (i.e., the Interpretant).

\subsection{On the Inadequacy of the Reality Represented by Kony 2012}

Although on all counts the IC "Stop Kony" campaign is found to be at fault by its critics, the harshest accusations are reserved for two of its sign components: what is told and shown as factual information, and the semiotic upshot that is aimed at by the IC NGO with their video. I begin by considering the fact-checking aspect of the campaign. The following blog entries (Izama 2012; 2012b) and a New York Times column (Izama 2012a) by Uganda journalist Angelo Izama furnish a fair illustration of the indignant denunciations of factual inaccuracies that are reported to be rampant in Kony 2012: "To call the campaign a misrepresentation is an understatement. While it draws attention to the fact that Kony, indicted for war crimes by the International Criminal Court in 2005, is still on the loose, its portrayal of his alleged crimes in Northern Uganda are from a bygone era. Besides getting the geography wrong, the video takes away attention from existing problems where the conflict festered for 22 years."

The blatant anachronism of the crime represented in the video is a flaw that for critics of the IC campaign calls into question the intellectual honesty of the entire project: if the war criminal Kony and the LRA have not been where the video says they are since 2006, everything else in its narrative is dubious. Besides the lack of basic fact-checking ("Criticizing the video is almost too easy," Izama 2012a), the video also omits any mention of present-day serious troubles in the region: "Today the real invisible children are those suffering from

${ }^{4}$ In Distant Suffering, Boltanski (2004) offers a description of the two centuries old development of this notion: "It is inherent in a politics of pity to deal with suffering from the standpoint of distance since it must rely upon the massification of a collection of unfortunates who are not there in person" (p. 12). Based on Hannah Arendt, Boltanski opposes it to "a politics of justice:" "For a politics of pity, the urgency of the action needing to be taken to bring an end to the suffering invoked always prevails over considerations of justice" (5).

${ }^{5}$ According to Visible Measures (2012), the Kony 2012 video gathered 100 million viewers in only 6 days, and thus it broke all previous records of quick popularity for a video on the internet. To have a clear idea of how important this quantitative outcome was, we can compare this amount with the one attained in more days by the likes of Susan Boyle's Britain's Got Talent, Reality TV musical hit or with Lady Gaga's Bad Romance clip, which took, respectively, 9 and 18 days to gather such an enormous following. 
Nodding Disease. Over 4000 children are victims of this incurable debilitating condition. It is a neurological disease that has baffled world scientists and attacks mainly children from the most war affected districts of Kitgum, Pader and Gulu" (Izama 2012). American activist Halpin (2012) takes the accusation of inaccuracy further: "It also ignores the work of Ugandan activists like Betty Bigombe. Not only is this a horrific erasure and distortion of reality, but, I have to ask, what good would the Kony 2012 campaign be even if they were right?" To put this kind of flawed information in semiotic terms, there is a refinement that Peirce made regarding what is represented by a sign. To account for human fallibilism in our use of signs to have access to the world, Peirce posits two distinct semiotic objects: the Dynamical Object, or "the object outside of the Sign" (EP2: 480), i.e., reality as it is outside the process of sign action, and the Immediate Object, "the object as the sign represents it" (EP2: 482), which by definition is less complete or comprehensive than the Dynamical Object. Every Immediate Object is a fallible, partial revelation of the Dynamical Object through the action of signs generating interpretants of it. Kony 2012 is accused of disregarding key components of reality and of revealing inaccurate ones. Hence the use of expressions such as "horrific erasure" or "distortion" to denounce a deliberate strategy of the makers of the video to depict inaccurately the actual situation in present day Uganda regarding the exploits of Kony and the LRA for their own purposes. ${ }^{6}$

The negative views concerning the information in Kony 2012 are related to "the architecture of participation" (O'Reilly 2005, quoted by Jenkins 2009a) of our networked society. This problem was envisaged implicitly some years ago by Castells and Arsenault (2006), when they predicted the overcoming of commercial media manipulation by a more democratic informative landscape, which involves "the rise of a concerned citizenry more involved in public affairs" and "the development of alternative, horizontal networks of communication that bypass business media while keeping an appropriate level of accuracy and credibility in the content of their messages" (p. 303). The "level of accuracy" is precisely what is at stake for most of the voices of the critical backlash to the IC video.

Another unanimous objection raised to the correctness of the information conveyed by the IC video stems from its oversimplification of a very intricate geopolitical situation. In her sarcastic depiction of Uganda's history of colonialism, Edmondson (2012) argues that its past has made it an ideal geographical setting for this kind of information impairment: "The [Kony 2012] video was familiar in its self-aggrandizing, sensationalist, and oversimplified representations of the complexities of conflict and post-conflict Uganda. In each incarnation, Uganda is infantilized" ( $p .11)$. What she denounces is a willful distortion of facts caused by an utter disregard for reality, so that this NGO can present convincingly its own reductionist views. To this end, IC needed to create an infantile tale of an archvillain, the LRA leader Joseph Kony, and of his pitiful young victims. Concerning the latter, a blatant absence deplored in the video relates to its racial ideology: the voice of the local people telling their own story is missing. Nigerian-American writer Teju Cole (2012) invokes "The White Saviour Industrial Complex" to explain this indefensible omission: "There is the idea that those who are being helped ought to be consulted over the matters that concern them."7 This racist, neo-colonialist attitude accounts for, writes Finnegan (2013), the glaring gap between the real and its audiovisual representation: "Africa has largely been treated as an object, and 'as an object, Africa is described and manipulated, but Africans cannot speak for themselves or make comments on who we are' (Keim 2009: 11)" (p. 143). Finnegan (2013) concludes that the representation of a voiceless local population is not just a flaw of the IC video: "This form of othering allows those with power to deem that the sources of social problems that need to be addressed are alien and belong to those African people" (144).

\footnotetext{
${ }^{6}$ Many of these accusations were handled by the NGO in another video, Kony 2012: Part II - Beyond Famous (Invisible Children. 2012b), uploaded a month after the first video, on April 5, 2012.

7 The phrase alludes to "the white man's burden," from an 1899 poem by Rudyard Kipling, which is mentioned explicitly by Nothias in his critique of Kony 2012: "the simplistic narrative of this video [reinforces] the idea that the West must save Africa, where people are helpless victims of evil men" $(2013,125)$.
} 
Uganda journalist Kagumire (2012) voices a similar sentiment in a video that she uploaded shortly after (March $7^{\text {th }}$ ) Kony 2012 started gaining its vast audience. What she finds painfully missing from it is the very agency of the people that this NGO aims to help:

How do you tell the story of Africans? It's much more important what the story is, actually, because if you are showing me as voiceless, as hopeless... you shouldn't be telling my story if you don't believe that I also have the power to change what is going on. And this video seems to say that the power lies in America, and it does not lie with my government, it does not lie with local initiatives on the ground that aspect is lacking. And this is the problem, it is furthering that narrative about Africans: totally unable to help themselves and needing outside help all the time.

The next critique of the video that I consider relates to the interpretant, in it Halpin (2012) links the inaccurate facts of the Kony 2012 narrative with its aim as a discourse. Her claim seems counterintuitive: even if the filmmakers had got the facts right, this campaign would have been useless. Her criticism moves the discussion to the area of the video's meaning, i.e., the generation of the interpretant as the logical effect of sign action.

\subsection{The Contentious Link Between Acquiring Awareness and Taking Genuine Action}

It is somewhat ironic that the idea of the media virus emerged at the same time as a shift towards greater acknowledgment of consumers as participants in meaning making within the networked media space. (Jenkins 2009a)

The controversial, overt aim of the "Stop Kony" campaign was to make a man accused of heinous crimes famous, an instant negative celebrity, and to achieve that goal through intense networking, i.e. by getting the viewers of the Kony 2012 video to share it through the system of SNS (social network services such as Facebook, Twitter, etc.), and to write to a celebrity from a list furnished by IC. Kony's increased visibility to the population would then turn into pressure on the US government to keep sending military aid to capture Kony. This would put an end to his misdeeds. Why this new-fangled Dead or Alive poster transformed into a YouTube film produced such a fierce backlash, despite the vast audience that it gathered in record time? To answer this query I will avail myself of Peirce's technical notion of meaning effect, the interpretant.

Many critical voices question the possibility of any plausible connection between becoming aware of a crime (whose atrocity no critic questions) - the overt purpose of the IC video and being thereby capable of changing that sad state of affairs in Africa. To make her case, Halpin (2012) compares IC's audiovisual campaign pejoratively with another for social change sponsored by the Advertising Council of America: "It's easy to laugh at them, and it's pretty obvious how little effect they have on anything. There's a reason the Advertising Council is behind so many awareness campaigns: they are advertisements."

African-born novelist Dinaw Mengestu (2012) also criticizes the efficacy of awareness as a prerequisite for taking positive action: "Kony 2012 self-indulgently promises all of this will change because now we know, and thus we have the power. If there is one thing Invisible Children is right about, it's that ignorance is blinding." In his view, no amount of awareness will empower its viewers to change things for the better. The critic's sarcasm - the blinding ignorance attributed to this NGO - recurs in many of those who discuss this point: awareness is oversold, as they do not see a positive link between the signs that represent something, even if they do so accurately, and positive subsequent actions about what is revealed of the object by those signs. American activists Cronin-Furman and Taub (2012) make a similar argument: "But campaigns like Kony 2012 don't claim to operate for the edification of the Americans they target for 'awareness.' They promise that awareness is a path to solving the problems being publicized. That's a problematic promise. There is no quantity of awarenessraising wristbands that will cause $\mathrm{J}$. Kony to abandon his fight."

This critical position is not unanimous, though, as it is the case with the denunciation of the inaccuracy of the facts narrated. After describing her first-hand knowledge of similar 
campaigns for African human rights, Shannon (2012) considers the case of Kony 2012 in positive terms: "This is the power of awareness. The greatest challenge in accomplishing these goals has been the silence, especially in Somalia. Awareness is vital to our fundraising strategy, catalyzing the global conversation." Gregory (2012) uses two complementary terms to describe the impact of web-based campaigns such as Kony 2012: "spreadable," which is similar to the idea of viral communication, and "'drillable,' which means that a person can dig down and understand easily beyond the core message and narrative and have a depth of voice and context" (466). He believes that "it is to be hoped that future Kony 2012s will strive to incorporate more intentional drillability alongside their powerful spreadability" (467). The functioning of these concepts resembles that of the interpretant. An advantage of using this semiotic notion is that we avoid being optimistic or pessimistic on this matter, i.e., the upshot of a web-based campaign. We do not have to choose intuitively whether media saturation about an issue - a flood of information about a humanitarian crisis - results or not in a concrete upshot. The issue can be analyzed through a refinement of the interpretant.

The "immediate interpretant" is that "which (the sign) expresses, all that it immediately expresses." The "dynamical interpretant" is "the actual effect it has upon me the interpreter" (EP2: 498), and "the final interpretant" is "that which would be decided to be the true interpretation" (EP2: 496) in the long run by a scientific community. Each critical view considered so far regarding the meaning effect of Kony 2012 is a dynamical interpretant, and so is the critical video response uploaded by Kagamure (2012) I quoted above. Regardless of its ethical or informative values the consensual construal of Kony 2012 as a humanitarian campaign stems from the pre-interpreted nature of the video as a sign, i.e., from its semiotic characteristics. This is the immediate interpretant as a range of interpretability. The actual interpretations elicited by the video are its dynamical interpretants, the concrete, perceptible effects in the world (e.g., a video on YouTube, a blog, a newspaper column). The other two interpretants are not concrete: one is a series of possible interpretations, the plausible meaning of something even before someone interprets it, the other is a tendency towards a certain cognitive outcome as the result of the interpretative work of a community of inquiry.

As an interpretant is also a sign, it generates further signs of itself, as time goes by and as reality evolves. This idea is nicely captured by Jenkins (2009) in his critique of the notions of virus and meme, both of which, he writes, derive from "metaphors of infection and contamination." Jenkins considers this way of speaking a kind of biological reductionism that jeopardizes the importance of human agency. As an alternative term, Jenkins (2009a) proposes the notion of "spreadability," which "describes how the properties of the media environment, texts, audiences, [...] work together to enable easy and widespread circulation of mutually meaningful content within a networked culture. In this emerging model, consumers play an active role in 'spreading' content rather than being the passive carriers of viral media: their choices, their investments, their actions determine what gets valued in the new mediascape."

Instead of attributing great power to the popular Kony 2012 or none at all, we can consider the continuous generation of interpretants of the dynamical object, then it follows that the information packaged in the video, its meaning, expands and becomes more complex. This could help to explain the unforeseen lack of success of the offline climax of the Stop Kony campaign: Cover the night (Carroll 2012). ${ }^{8}$ This was supposed to be a massive city intervention in which thousands of posters with J. Kony's face would be hung in cities all over North America during the night of April 20, 2012. The idea of meaning growth through the generation of interpretants brings about a degree of complexity to the campaign that can be appreciated in Blattman's (2012) blog. He wonders whether the IC campaign is a perfect example of advocacy gone wrong - "badvocacy" - or if anything good came of it: "For all its weak-

\footnotetext{
${ }^{8}$ Greenblatt (2012) gives a different account of this disappointing outcome of the campaign outside the internet. For him the poor result is an effect of the short attention span of internet audiences: "The campaign to 'stop Kony' may have briefly captured their attention, but it appears that most students have moved on." On the same day, April $20^{\text {th }}, 2012$, in the College of William \& Mary in Williamsburg, VA, there was an attempt to break the world record of spooning, and it was far more popular than the Stop Kony campaign planned for that day: "As of Thursday morning, 625 people had 'liked' the spooning event listing on Facebook. By contrast, a moribundappearing page called Kony 2012 William \& Mary had just 16 likes."
} 
nesses, Invisible Children has been more effective than any of us at raising awareness [...]. What's new and amazing is that, with the direction that coverage has taken, the average high school activist, donor and Congressman might just understand a little better what separates advocacy from badvocacy, and demand better in future. And that makes me hopeful."

After she reviews the backlash "against the Kony 2012 video" and the concern of its being "a misguided call for intervention," Tufekci (2012) argues in favor of it because it created a more complex meaning than the video was meant to produce: "This time, thanks to the emergence of a global networked public that can now talk back, a simplistic call is rapidly evolving into a multilayered discussion." To understand why so many critics rejected the possibility of any causal link between the massive public awareness about an issue through heavy media exposure and a positive outcome of social commitment, I will revisit a classic antecedent in media studies which postulates the paradoxical lack of genuine social commitment despite people being aware of a social problem through increased media exposure.

\subsubsection{An Attempt at Explaining the Kony 2012 Backlash through Early Functionalism}

What does it take to evolve from society being informed by mass media about some social issue, e.g., a problem in which it is reasonable that citizens should become involved, and their actually doing that which is expected of well-informed people? That is the question which two founders of the field of communication studies tried to answer over half a century ago, in a seminar of the Institute for Religious and Social Studies, in New York. Their ideas were published in a volume that includes another classic text. ${ }^{9}$ In 1948, Paul Lazarsfeld and Robert Merton presented a functionalist analysis of mass communication; despite the label of "administrative" research that critics used for the approach of Lazarsfeld and his associates, on that occasion they introduced a critical element into the functionalist model. ${ }^{10}$ The socalled "dysfunction" consists in a paradoxical, negative influence of the media that instead of contributing to the social order produces a detrimental effect on society, hence its odd name of (latent) 'dysfunction:' "This may be called the narcotizing dysfunction of the mass media. It is termed dysfunctional rather than functional on the assumption that it is not in the interest of modern complex society to have large masses of the population politically apathetic and inert" (Lazarsfeld and Merton 1948, 105-106). Such is the paradoxical effect that occurs when a manifest function of mass media proves to be a latent dysfunction: "exposure to a flood of information may serve to narcotize rather than to energize the average reader or listener" (ibid.). This notion enabled these pioneering media scholars to explain why "the interested and informed citizen [...] comes to mistake knowing about problems of the day for doing something about them" (106, emphasis in the original). Baran and Davis (2009) offer a historical instance of the narcotizing dysfunction: researchers concluded that "extensive, often dramatic coverage of 1950 congressional hearings concerning organized crimes did not lead to widespread demands for government action" (179).

Half a century before the postulation of this odd "dysfunction" of mass communication, Peirce proposed a thought experiment that sheds light on this vexed issue. In 1903, in one of the Harvard Lectures, Peirce posited a question that he conceded was too hard to answer with the knowledge available then: "How do (symbols or words) produce their effect?" (EP2: 184). He uses the notion of "mediation" to account for an effect that does not consist in symbols directly reacting upon matter. But if we admit that symbols do act upon things, as they undoubtedly do ("Words then do produce physical effects. It is madness to deny it" (EP2: 184), how does that effect come about? Peirce's puzzlement regarding symbolic action is akin to the problem that Lazarsfeld and Merton (1948) faced when they came up with a disruptive function of mass communication so as to preserve their theory of communication. The narcotizing dysfunction does not make media users better prepared to deal with the world,

\footnotetext{
${ }^{9}$ It is Lasswell's five-term model of communication, which is another chapter of The Communication of Ideas (Bryson, 1948): "The Structure and Function of Communication in Society."

10 Jerabek (2011) traces back the history of the fruitful collaboration between the sociologist Merton and the psychologist Lazarsfeld, and points out that the narcotizing dysfunction "conforms to Merton's theory of the 'latent' or 'unthinking' function of media" (1205).
} 
but rather the opposite; the negative qualifier "narcotizing" alludes to an element that dulls human perception and makes it less capable of adapting to the environment.

To understand the working of mediation, i.e., how signs such as those transmitted by the media have a certain effect on our lives, Peirce (EP2: 184) proposes a mental experiment. He invites his audience to imagine what would happen if by accident, an American schoolboy dropped a slip of paper from a ship sailing the Pacific Ocean. The text that the child wrote on that piece of paper was the inflammatory passage drawn from a celebrated speech made by American revolutionary Patrick Henry on March $23^{\text {rd }}, 1775 .^{11}$ What would have happened if those signs had been able to surmount the formidable obstacles of a tremendous distance and a foreign language (Tagalog)? Peirce believes that if those written signs had been conveyed by that primal means of communication (= the sea), they would have been capable of exerting a revolutionary influence on that remote community. Patrick Henry's words would have produced the same emancipatory effect that they originally had on the dwellers of $18^{\text {th }}$ century America, on the people of "the isle of Luzon" (present-day Philippines), which Peirce imagines as the arrival point, a century later. The reason why those symbolic signs would be able to transcend their local circumstances is that "those words present (the) character of the general law of nature, that they might have produced effects indefinitely transcending any that circumstances allowed them to produce" (EP2: 184).

Back to my case study, to the critical backlash against Kony 2012 in our internet powered $21^{\text {st }}$ century, we read: "Even at the height of the video's popularity, there were questions about whether teenagers tweeting it would turn awareness into action" (Greenblatt 2012), and a similar idea in Madianou's (2013) skeptical remark: "What we observe in (IC's) campaign is a fetishization of action which is decoupled from an understanding of the causes or contexts of suffering" (p. 260). But that is precisely the issue discussed by Peirce semiotically, when he writes on "the essential nature of signs" (EP2: 311). Despite the denounced flaws of the IC internet campaign, what is there to stop it from producing "effects indefinitely transcending any that circumstances allowed them to produce?" To conclude, as most critics do, that no amount of awareness can bring about any real change in the world, ${ }^{12}$ is to think not in terms of the triadic power of signs, whereof Kony 2012 is a concrete instance, but in terms of the dyadic effect of their material replicas or embodiments (oral, written, visual, etc.). Signs work through such concrete elements, but they do so to generate and guide certain general patterns of behavior. To study anything semiotically, wrote Ransdell (1979), does not mean to ignore that it has qualitative and material aspects too. It means that we are specifically interested in the relational property, the mediation of signs, whose "essential function is to render inefficient relations efficient, -- not to set them into action, but to establish a habit or general rule whereby they will act on occasion" (CP 8.332).

Mengestu (2012) seems not to realize this in his bitter denunciation of the IC campaign: "The doctrine of simplicity is always at war with reality. You can't put that on a t-shirt or a poster. You can't tweet that, but you can live by it." His claim confuses the actual tokens of communication - the kit offered for sale to supporters by the NGO- with the work of signs. The latter cannot be easily dismissed, since it evolves and makes meaning more complex: "Symbols grow. They come into being by development out of other signs. [...] So it is only out of symbols that a new symbol can grow" (EP2: 10). Triadic semiotic brings the possibility of going beyond pessimism or optimism to critical visual theory, and to consider the developmental way of signs. In the age of "posthumanitarianism" and "hyper-celebritization" (Chouliaraki 2011, 15), even a flawed web-based campaign can bear good fruits.

\footnotetext{
${ }^{11}$ The words of Patrick Henry are: "Is life so dear, or peace so sweet, as to be purchased at the price of chains and slavery? Forbid it, Almighty God! I know not what course others may take; but as for me, Give me Liberty, or give me Death!"

12 To be fair, some critics speak of effects of the IC video, but they only refer to negative, unintended consequences. Izama (2012b) writes: "That cult of fear was immortalized earlier this month when the film Kony 2012 went viral on the Internet." Levin (2013) denounces its ethically biased representation of the child soldier: "A consideration of such erasure, comprised of making the soldier invisible, raises crucial questions about the damage done to a subject's dignity and self-determination by refusing to see him in his totality is its essential precondition" (106 - emphasis added, F.A.).
} 
Below, I advance a possible explanation for the almost unanimous note of hopelessness regarding the meaning of such campaigns; interestingly enough, it involves a failing that is akin to the one most often denounced in IC's video, namely, oversimplification, the demonization of the other in that narrative, be it the archvillain (Joseph Kony) or the othering which silences every trace of genuine, human agency (the victims of the LRA). From a semiotic perspective, this neo-narcotizing dysfunction diagnosed by critics regarding the high impact of Kony 2012 is not warranted by the working of signs, by the process of mediation described in Peirce's thought experiment. The improbable but conceivable sea journey of signs shows their power, even if those revolutionary signs were not addressed to the distant society where they end up having a political, radical effect. Indeed, posters or bracelets are material things, tokens of what Chouliaraki (2011) calls the "commodification, which spectacularizes suffering" (p. 6), examples of the "entrepreneurialization of humanitarianism in the name of "getting things done'" (p. 14). But they are also signs, elements whose growth and power is not reduced to that embodied level and which is therefore difficult to predict.

\subsection{A Compelling Moment of the Kony 2012 Narrative: The Video's Index Appeal}

Now I discuss the representamen component of the IC video, the signs which set up the stage for the story told in Kony 2012. Why those iconic and indexical elements of this narrative exerted such an unusual attraction for so many viewers? When they consider the images and sounds that shape the video's story, even the most vocal critics describe it as "compelling:" "Jason Russell, the film's director and narrator, shar[es] a compelling narrative about how he became involved in this effort" (Goodman and Preston 2012). Normally, this semiotic feature would have been considered a merit of the campaign, but it contributed to its being judged as contemptible also in terms of its representamen. A scholarly article that is an exception in that it gives warm praise to IC' video, ${ }^{13}$ describes its audiovisual narrative technique as follows: "The films that IC produces have been successful in captivating and engaging their audiences. Kony 2012 and all of IC's previous films focus on an important subject, but they also, and equally importantly, tell a compelling story. First-person narrative is often a successful way to reduce 'psychological distance' between the viewer and the subject" (Kerstin and Matthew 2012, 258-259).

Greenblatt (2012) draws attention to the personal element in the video: "Part of the power of Kony 2012 was the way Russell was able to personalize the cause, showing how he and his young son had come to understand the menace and impact of Kony and his group, the Lord's Resistance Army." In his blog entry, ${ }^{14}$ Gregory (2012) has a link to the scene in which the director and protagonist of Kony 2012 shows the photograph of Kony in military fatigues to his five-year old son Gavin. ${ }^{15}$ This informal lesson about the crimes of the LRA leader comes at 9'15" of the half-hour long video, directly after a monologue of one of its victims, an adolescent called Jacob, who tells Jason about his dead brother, whom he still sees in dreams. After his testimony, Jacob can't hold back his tears. "Can I tell you the bad guy's name?" Russell asks his son, while he points to a photograph of Kony that he places on the table. Then he brings another picture of a happy looking Jacob, and puts it right next to Kony's photo, whose stern expression seems even harsher. Gavin quickly identifies the boy by his name. In very simple language, the father then explains to his son how Kony forces Jacob and other children like him "to do bad things," such as killing people. While we watch Gavin having a hard time to assimilate the shocking facts, after an attempt to deny the infor-

\footnotetext{
${ }^{13}$ It is likely that this journal article was published before the outset of the backlash to the video. It was written in 2012. Since it normally takes a few months for a paper to be approved by the peer review process, the events that happened after the date the manuscript was completed could no longer be taken into consideration.

14 Kony 2012: Juggling Advocacy, Audience and Agency When Using \#Video4Change, accessed April 25, 2013.http://blog.witness.org/2012/03/kony-2012-juggling-advocacy-audience-and-agency-when-usingvideo4change/

${ }_{15}$ Accessed on May 12, 2013. http://www.flickr.com/photos/humanrights/6842641702/ .
} 
mation, ${ }^{16}$ his father wants to know what Gavin thinks about this: "It's sad!" says the boy slowly in a sad, solemn way that makes him look older than his age, and exits the scene.

What we have witnessed - and the collective pronoun is here made up of a huge audience is a forceful instance of the film's "index appeal" (Andacht 2010). This notion describes the distinctive and prevalent component of the TV genre reality show and its more respectable ancestor, the documentary. It consists in the prevalence of the signs that represent their object through a factual connection with it, namely, indexes (CP 4.447). Such are the bodily symptoms (tears, blushing, sweat, etc.), which are perceived as being authentic by viewers of factual TV programming or documentaries. The basis for such a belief is the same that we find in Goffman's classic distinction between "the expression that (the individual) gives" and "the expression that (the individual) gives off" $(1959,2)$. This is the opposition between intentional signs, such as words or conventional gestures, and involuntarily displayed emotions, such as a nervous stutter. The simplest kind of sign is the iconic: a quality that functions by analogy with the object it represents. Due to an "inclusion rule" (Liszka 1996) a more complex sign involves a simpler kind; indexes involve icons. The physical features of the two boys represented - Jacob and Gavin - are iconic of their objects. But what is decisive for the narrative to become "compelling," as critics said, is the revelation of their emotions through signs that are independent of their will, such as Jacob's tears and Gavin's shocked look, once he hears about the crimes committed by Kony against children. Levin's (2013) term "haptic" serves to describe the index appeal of IC's video, although this notion is part of his critical contrast between Kony 2012 and Neil Abramson's Soldier Child 1998 documentary on the same subject. The latter's achievement, Levin argues, lies "in transmitting something beyond the visual through a certain rupture of vision, a rupture that is both haptic and present" (p. 117). Levin (2013) writes that through its use of clichéd human rights rhetoric, the IC video makes invisible the unsettling "contradictory subject positions of victims and perpetrators" (115) of the children kidnapped by the LRA.
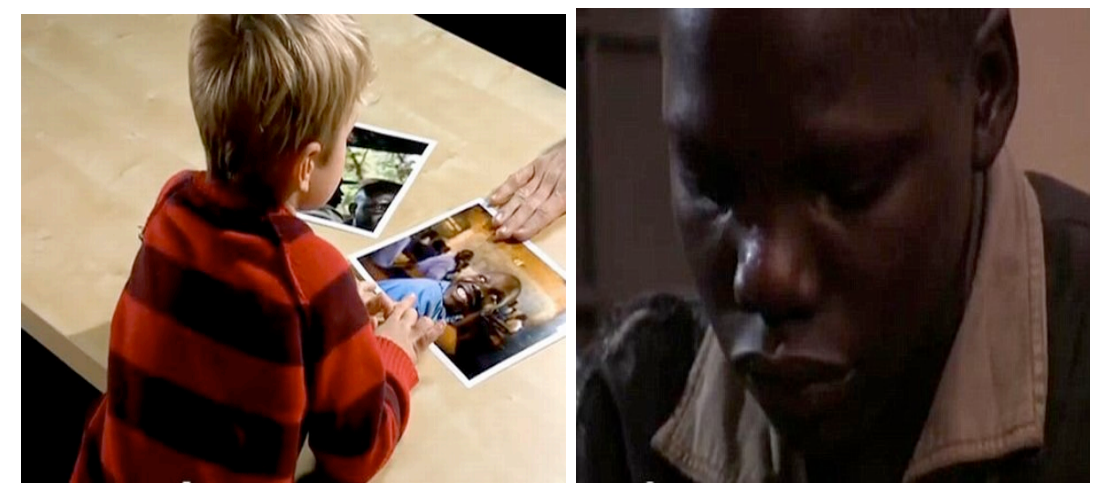

Figure 1: Jason Russell's son, Gavin, looking at the pictures shown by his father (left); Jacob Achaye, a former child soldier of the LRA who managed to escape (right). Both images are from Kony 2012. ${ }^{17}$

Though I agree with Levin's (2013) rhetorical and ideological analysis, I also find much to agree with in the simpler take of Bradshaw (2012), whose film review of Kony 2012 finds it wanting as a documentary but not as a web-based campaign: "And are we, the audience, being talked down to? Treated like kids? Well, yes, a little. But there's no doubting the force of this film," which is "a piece of digital polemic and digital activism." For The Guardian's film reviewer "it is quite simply brilliant. Russell isn't afraid of brash emotionalism. He tugs and wrenches at the heartstrings" (Bradshaw 2012). The index appeal generated by the home

\footnotetext{
16 "But they are not going to do what he says, because they are nice guys, right?" Gavin asks his father, with a look of hope, as if the child expected that what he just heard could never apply to the boy that he knew.

17 Gavin's image comes from http://lifemarginally.wordpress.com/2012/03/12/everybodys-doing-it-kony-2012/ , accessed May 30, 2012, and Jacob Achaye's image is from http://metro.co.uk/2012/03/10/kony-2012-childsoldier-jacob-acaye-viral-video-brought-back-memories-347597/, accessed August 25, 2012.
} 
movie rhetoric of the "Stop Kony" campaign is arguably one of the features that made it so compelling for its numerous viewers and also so objectionable to critics such as Levin, who finds this kind of representation symptomatic of "the infantilizing narrative" $(2013,114){ }^{18}$ There is an essay whose title mocks the presence of the child in IC's video: "What Jason Didn't Tell Gavin and Other Critiques of Invisible Children" (Mamdani 2012).

Like Jacob, the former child soldier of the LRA who is seen in the video as a frail and psychologically wounded human being, and who cannot restrain his tears, as he evokes the memory of his dead brother, Gavin, Russell's child, brings persuasive indexical signs of wholesome looking authenticity to the video and thereby to the entire campaign. Predictably, these images are found to be objectionable by the critics: "The viewer is put in the position of Gavin, the son of Jason Russell, founder of IC. Jason, a young white American, tells the story of the promise he made to Jacob, a Ugandan teenager formerly abducted by the LRA, to catch Joseph Kony, the leader of the rebellion. Taken together, these characters epitomize three recurrent stereotypes that have pervaded Western representations of Africa: the good, willing Westerner, the helpless African and the cruel warlord" (Nothias 2013, 125).

The sarcasm of Mengestu's (2012) essay becomes scathing, when he denounces the oversimplification regarding Kony and the LRA as it is represented in the images that Kony 2012 used to persuade viewers of the suitability of their proposed military solution: "There isn't the time to offer a more complete portrait, which could be true if so many of those thirtyminutes weren't spent on Hallmark images of college students putting up banners and of Jason and his son." A critic refers to the factory of the imaginary iconography in the West: "In fact, in many ways, it was like a Hollywood film, carefully constructed to elicit an emotional response with a minimum of thought involved" (Butcher 2012). What is described as the "slick" production values of the video (Curtis and McCarthy 2012; Halpin 2012; Shannon 2012) are found to be responsible for arousing strong emotions, those typical of "posthumanitarianism" (Chouliaraki 2011): a decadent form of modern humanitarianism that jeopardizes any real awareness in viewers of the film, the alleged goal of the IC campaign: "The image of a doe-eyed, tearful kid affects most of us on a subconscious level, because protecting kids is something hardwired into the majority of us. We react viscerally to it; we have no choice. And the propagandists know that" (Butcher 2012).

In her defense of "social awareness" as a valid form of advocacy and of Kony 2012, despite acknowledging its mistakes, Margon (2012) raises an interesting point about the function of images, which is relevant for a semiotically informed critical visual theory: "Video campaigns provide a powerful foundation of social awareness that can help move us all toward more robust policy options. Because they are appealing to a broader audience, innovative technology tools are inevitably going to be different from more traditional ones, but that doesn't mean they are harmful or unhelpful."

Boltanski makes a similar point when he claims that the visual component of humanitarian campaigns as a way to arouse emotions in humanitarian campaigns does not necessarily weaken the viewers' understanding of the crisis thus represented:

In relation to the media, the spectator occupies the position [...] of someone to whom a proposal of commitment is made. A different spectator, who recounts a story to him, and who may be a reporter [...] an eye-witness, [...] conveys statements and images to a spectator who may take them up and, through his words, pass on in turn what he has taken from these statements and images and the emotions they aroused in him. Far from passively absorbing the spectacle put before them, television viewers put to work important critical capabilities. (Boltanski 2004, 149; emphasis added)

\footnotetext{
${ }^{18}$ Suspicion of the humanitarian rhetoric is a traditional topic whose history Boltanski (2004) traces: "From the end of the eighteenth century, sentimental and sentimentalism are especially singled out for criticism" (99). The use of emotions for humanitarian aims is an object of contempt and suspicion because "the appeal to sentimentality enables the spectator to be manipulated and dulls his critical sense" (103). Writing about the danger of sentimentalism, Nibbe claims that "a constant barrage of images of African children infantilizes the continent in the consciousness of the international community (2010)" (quoted in Finnegan 2013, 151).
} 
At least part of the bitter rejection that met this attempt to put into images the ordeal of those who suffered under the ruthless oppression of the LRA could be explained by an iconophobic tendency in Western society. The term refers to a deep-rooted tendency that can be traced back to the outset of modernism, one that grew under the influence of "the dominant philosophers Descartes, Hobbes, and Locke, in the early $17^{\text {th }}$ century" (Ransdell in Andacht 2003, 228). It was then that the belief in the superiority of the verbal mode compared with the visual was firmly established. This suspicion of the iconic assumes that images - iconic signs cannot produce increased reasonableness, since that would be the prerogative of symbolic signs. From that philosophical belief to present-day iconophobia, there was only a step, what Ransdell calls "the curmudgeon spirit" of our own times, which is antagonistic to iconicity and its much feared effects on the human imagination: "The curmudgeon spirits who believe that safety depends upon imprisonment and constraint rather than cultivation of possibilities tend to oscillate between the denial that there is any meaning in images at all other than what is put there by words, and those who recognize that there is but see it as a subversive power insofar as it adds anything to what words bring to it by way of control of it" (ibid., 224).

Ransdell's semiotic contribution to a critical visual theory entails our accepting that far from being inferior or subordinated to symbols, the epistemic value of iconic signs lies in the fact that "it is part of the function of the symbol to introduce an icon of the object indexed" (222). For communication to succeed, the words used must be capable of producing cogent images in their audience. The international editor of Channel 4 acknowledges what the critical voices of the Kony 2012 backlash seem reluctant to admit:

None of the articles I or a hundred other journalists who have covered Uganda over 25 years has reached the people this video has reached. Ok, it may not be accurate. It may use out-of-date figures. But it's struck a chord that we have never managed to strike. The "Invisible Children" campaign could learn a little from those of us who care about accuracy and context. But I think we could learn something from them about how to get a message across, and how to talk to a generation that has stopped bothering to read newspaper and watch TV news. (Lindsey Hilsum, quoted in Nothias 2013, 127)

These are two of the abundant critiques of the visual component of Kony 2012 as a legitimate medium for that campaign: on its attractive images, Halpin (2012) writes: "Awareness campaigns, like most advertising, have become slicker and more intimate in the age of social media". For Madianou (2013) it lacks true affect: "Although Kony 2012 invokes emotions of identification, the cause itself continues to be largely de-emotionalized" (259). The comparison of the campaign images with an advertisement or the claim of the lack of true emotions reveal the irritation of critics regarding what so many people found interesting.

These examples are typical of the backlash; in them critics fall prey to a risk about which Kingwell warns intellectuals who pursue "a critical engagement in a media-saturated culture" $(2002,7)$. They should keep in mind that "taking up a critical stance against hegemony is really a form of dominating dominance [...] Why intellectual domination rather than cultural, after all?" (ibid., 14). If critics follow the Gramscian recommendation, namely, to "have one foot outside the bewitched circle, to be in the culture but not to be of it" (ibid.), they may find themselves without a valid stand from where to criticize culture "as long as critical distance is conceived in this externalist fashion" (15).

Images and sounds in Kony 2012 function preeminently as iconic signs. Hence the invidious comparison with verbal signs or symbols, which are thought to be the only type of signs which convey reliable knowledge. Although the profuse factual inaccuracies of the IC video are undeniable, my aim is to point out the existence of an iconophobic ideological tendency that hinders the critical take on this video.

\section{On the Risks of Dualism for Critical Visual Theory and a Synechistic Antidote}

Now I want to bring to the readers' attention another troubling aspect of the backlash to Kony 2012. It is an ideological blind spot in the well-justified critique of what became the most suc- 
cessful internet-based humanitarian campaign in the age of SNS. Through synechism, the metaphysical principle of logical continuity of semiotic theory, I analyze an unintended upshot of this critical discourse which reproduces a central flaw of a visual discourse that was accused of turning a complex geopolitical situation in Africa into a Hallmark-like cliché.

Granting that the many deficiencies of Kony 2012 are as bad as critics claim they are, we should be concerned when what is most criticized in it is also found in the critical discourse against it. This involuntary reproduction of what is so vehemently condemned in the IC video, I argue, is a consequence of the dualism underlying those critiques. A way to avoid this negative outcome is to rely on logical continuity, the synechism at the root of Peirce's semiotic model, the doctrine that does not admit dualistic discontinuities in the universe.

In the critiques I consider below there is a dichotomy at work regarding the public of the audiovisual signs of Kony 2012 that is older than the functionalist postulation of the "narcotizing dysfunction" (Lazarsfeld and Merton 1948), although this dichotomy is also an upshot of it. The opposition in question is that between active and passive (audience), the dualism which is at the heart of mass society theory (Baran and Davis 2009, 44-61) since the end of the $19^{\text {th }}$ century and the early $20^{\text {th }}$ century, which construed the mass media audience as a voiceless (brainless?) crowd of helpless victims of the dreaded direct media effects. This media theory originated the "magical bullet" notion, which was used to describe the effects of a humanitarian campaign such as "Stop Kony" more than a century later. Baran and Davis (2009) criticize the ideology of advocates of this early theory of mass communication lacking empirical support: "All mass society thinkers were unduly paternalistic and elitist in their views of average people and the ability of media to have powerful effects on them." ${ }^{19}$ Two metaphors describe the direct effects of mass media: a magical bullet and a hypodermic needle; both refer to the submissive role of media audiences.

Mosco and Kaye (2000) reflect upon the history of a now taken for granted notion in communication studies: "It is a theory-laden notion which should not be taken for granted in spite of its currency in academic studies of mass communication" (31). They express surprise at the universal acceptance of a notion that does not originate in any theoretical model ("in spite of its lack of a disciplinary or intellectual history" [32]) and has an undeniably commercial origin in marketing departments "with a stake in selling products through the media, the term audience has over time become embedded within the literature of mass communication studies (and it turned into) a central conceptual linchpin" (33). A taken for granted audience passivity is found in much of the critical backlash to Kony 2012, when it comes to drawing conclusions without empirical evidence regarding the actual public of the video. To denounce those who have viewed the video and decided to contribute to the IC campaign, as being lazy ("slacktivists"), self-centered ("narcissists") and as utterly deprived of basic knowledge ("ignorance is blinding") as many critics do, falls prey to the dualistic mode of metaphysical thought that came about with the passive (mass) audience vs. active producers of the media dualism. Such ideology is part and parcel of the commercial concept of audience that has infiltrated communication research, as Mosco and Kaye (2000) argue.

\subsection{The NN-Word: An Explanation of the Fierce Attack against the Audience of Kony 2012}

My final consideration about the critical backlash to Kony 2012 discusses a term that recurs in the critiques, one that is borrowed from psychology and psychoanalysis but has now percolated our everyday language. In this case this notion reveals a deep-seated rejection, even a demonization of the other based on an oversimplification of its humanity, which is precisely what the makers of Kony 2012 are accused of having done, in their case regarding the LRA leader and the African continent, as a place of rampant evil forces and helpless, voiceless victims. But what if the critics are also guilty of creating a dreadful Other in their own discourse, when they describe what they consider the typical audience of the IC video? What

\footnotetext{
${ }^{19}$ Huyssens (1986) considers some key texts of emblematic (male) intellectuals of modernity (Flaubert, Nietzsche, the Goncourt brothers) and concludes: "Different kinds of empowered discourse consistently and obsessively genders mass culture and the masses as feminine" (191).
} 
should we call a critical discourse that demonizes the viewers who are keen on the images of Kony 2012 and decide to contribute to the campaign? What is the basis for concluding that those who respond positively to the appeal of the NGO's "Stop Kony" video only do so because they are narcissists, or because they are white (upper) middle class youth eager to appease their conscience through an all too easy, effortless motion of their computer mouse, or in the best of cases, because they are so irredeemably ignorant?

The term "NN-word" is proposed here to describe analytically the process whereby many critics of Kony 2012 end up reproducing the same ideological flaw that they denounce in the strongest terms as characterizing the campaign created by the American NGO Invisible Children. I refer to the unanimous denunciation of the video's oversimplification that distorts reality by creating images that are a caricature of what is actually the case and will have harmful consequences for that region of the world, for the people who supposedly the Stop Kony campaign wants to help. The expression "NN-word" alludes to the racial slur that is felt to be so damaging to the Other who is thus insulted that it can only be mentioned euphemistically through the abridged formulation "the N-word." To describe the demonizing of the Other that targets the public of Kony 2012 in critical discourse, I have duplicated the "N," to refer to the "new N-word," namely, narcissism. In contrast to the traditional N-word, the word "narcissism" can be bandied about freely by its users, without guilt, particularly when what is being denounced is related to the visual realm, to the kind of signs that are found suspicious by the iconophobic reflex described above. As evidence of this tendency I present some instances of the many pejorative references to the viewers that I drew from the critical backlash to the video. The criticisms are formulated in strong negative moral terms and they are a mirror image of the flaws that the critics find in Kony 2012 and in its makers.

A metaphor quoted by Finnegan to describe the typical viewers of the IC video reveals the dualistic construal of the public of Kony 2012 and is thus representative of this critical trend:

The homogeneity of the privileged collective of Invisible Children activists, which one informant termed "pretty Wonder Bread" is reflected in a common understanding of the world. Invisible Children is particularly appealing to many contemporary American young people because of its cultural resonance with the arts and the social location of members of the upper middle class who are more intrigued with helping the vulnerable other in Africa than with participating in explicit and contentious political activism. (Finnegan 2013, 147)

Although Finnegan has made a qualitative ethnographic study of the followers of this NGO, she makes strong generalizations about race, status, and ideology of the activists, and the audience of Kony 2012 imagined by some of the interviewees. Such inferences should have been based on a quantitative survey of this phenomenon. ${ }^{20}$ It does not bring reliability to her presentation of this imagined audience when Finnegan (2013) draws a comparison between this bad kind of advocacy, with what she considers the good kind, i.e., the fight against Apartheid in the United States: "Contrary to the record of antiapartheid activism and Africa Action, Invisible Children activism seemingly prides itself on its noncontentious, apolitical approach" (150). It is this soft, uncommitted kind of activism, she claims, that "allows activists to face less controversy and less personal implication" (ibid.). To make her case against the kind of people who are willing to be activists of IC or to watch Kony 2012 with enthusiasm and contribute to the campaign, Finnegan assumes that to take part in this campaign is more convenient ideologically than to help out those in need in their own communities: "If these privileged young people had chosen to reach out to others in their own communities, perhaps immigrants or poor people of color [...] the related issues would be much more intimately intertwined with their own politics and that of their families. In such a scenario, exposing underlying causes may even implicate themselves as beneficiaries of racism or a predatory economic system" (Finnegan 2013, 149).

\footnotetext{
${ }^{20}$ See for instance Finnegan 2013, 143.
} 
Although Finnegan never uses the NN-word in her article, its rhetoric takes for granted its existence by demonizing the other through over-generalization and oversimplification. For her, it all boils down to "the activism from privileged young Americans and their journeys of identity" (ibid., 157-159). The emphatic reiteration of the term "privileged" used next to the nationality of the members of the NGO IC, and of the public of the video throughout her text implies that the only reasonable motivation for their positive attitude towards this campaign is their self-centred disposition, an attitude that, she argues, obliterates the humanity of those who are represented as victims. It is remarkable that the author denounces that rhetorical ploy at work in the Kony 2012 video with terms that could easily be applied to her own depiction of this video's audience: "This continued symbolism of extreme otherness in American culture has meant that Africa has largely been treated as an object" (143). It is true that the African people on whose behalf the video of IC was made are silenced by its patronizing, ethnocentric narrative, as Finnegan and many other critics write, but what about the diverse attitudes of the many millions of viewers whose motivation does not correspond to the ethically challenged portrayal that she proposes on the basis of a qualitative study, or simply prejudice for the others? They are all being homogenized into a mass of narcissists.

Although Chouliaraki (2011) is not part of the backlash to Kony 2012, her work is quoted approvingly by many of the critics of the video. She claims that this is the age of "posthumanitarianism," a celebrity-based social behavior that has replaced traditional humanitarian values: "It encourages a narcissistic disposition of voyeuristic altruism rather than one of commitment to the humanitarian cause" (17). Celebrities were part of the traditional humanitarian cooperation, but she posits a contrast between the work of Hollywood actress Audrey Hepburn as ambassador of the United Nations, because "humanitarianism eclipses celebrity from her persona and promotes an unconditional altruism that capitalizes on her acting expertise to give voice to those who suffer," and the performance of Angelina Jolie as typical of the new "self-saturated" times. Chouliaraki argues that the strategy "hyper-celebritization" enacted conspicuously by actress Jolie "is an intensification of her celebrity persona" (10) which characterizes the new narcissist age regarding society's behavior toward distant suffering: "Post-humanitarianism brings into focus the function of the confessional celebrity as a medium of self-recognition, wherein aspirational discourse gravitates around the interiority of her emotion and, consequently, around those who reflexively mirror themselves in her - instead of other-recognition, wherein aspirational discourse engages with images and stories that orient us toward suffering others" (ibid., 15-16).

After considering some milestones in the colonial and post-colonialist history of Uganda, and reflecting ironically on what in that African nation makes it so attractive ("sexy") to the West's humanitarian aid, Edmondson (2012) concludes that for NGOs like IC the temptation to oversimplify matters about that nation is just too hard to resist: "Humanitarian narratives provide crucial access to the empire of trauma through the definition of subjectivity as victimhood. Uganda's prominence in the empire's gaze could be attributed to the theatricality of the LRA as well as the deceptive simplicity of the conflict. [...] Simpler is sexier. And the empire loves sexy" (ibid., 12).

Like most critical voices of the backlash to Kony 2012, Edmondson (2012) claims, "the video was familiar in its self-aggrandizing, sensationalist, and oversimplified representations of the complexities of conflict and post-conflict Uganda" (11). What I find most relevant in her article is its conclusion regarding the cause of the fascination exerted by Uganda as the quintessential helpless victim that lies passively waiting for the (male) intervention of the West. According to Edmondson, this hope has made Uganda a place of choice for narcissistic humanitarianism (instead of South Sudan or DRC): "Ugandans speak English, making it all the easier to understand their (post-conflict) tales of woe. And all the easier for the Euroamerican Christian male to indulge in his navel-gazing formations of self' (ibid., 12). Although the term "narcissism" is not used in Edmondson's (2012) article, her account of the desirability of Uganda as a favorite destination for humanitarian intervention of the West as the result of the self-indulgent viewers' "navel-gazing formations of self," and the fact that she imagines a gendered (male) gaze leave little doubt about an allusion to that pathology. 
Madianou's scholarly critique also invokes the troubling motivation of narcissism as that which makes present-day humanitarianism suspect or unacceptable: "Devoid of an emotional and moral grounding, posthumanitarian appeals become vulnerable - or choose to be too comfortably close - to a market logic which ultimately constitutes a "perpetuation of a political culture of communitarian narcissism" (Madianou 2013, 253).

By contrasting "communitarianism" and "cosmopolitanism," and quoting Chouliaraki's (2011) "post-humanitarian" theory, Madianou (2013) describes these two ideal types as complete opposites, when it comes to imagining and acting in relation to distant suffering represented in the media: "communitarianism constitutes a pessimistic scenario of global connectivity" (252), which lacks the kind of insightful "reflexivity" that is part of "the cosmopolitan version" of what new media such as SNS have now made available. Near the end of his article, after pointing out the insufficient suffering depicted in the video and its slogan "Make Kony famous" - (257-58), he concludes that Kony 2012 fosters the negative communitarian attitude of social media in humanitarian matters: "This celebration of citizen empowerment is 'ecstatic' (Chouliaraki 2006) and narcissistic" (259).

Nothias (2013) also bases his critique of Kony 2012 on this negative turn in the path of contemporary humanitarianism: "It relied entirely on social media; it promoted its audience of donors much more than the one of suffering distant others" (125). Its dualistic thinking is explicit. What is thus being denounced is a revisited "narcotizing dysfunction" of the internet age. From this critical perspective, what popular web-based campaigns do to their enthusiastic viewers is to create a pitiful confusion: to paraphrase Lazarsfeld and Merton (1948), members of that multitudinous audience come to mistake knowing (positive things) about themselves, with knowing or doing something (socially productive) about distant others who are suffering.

Although the success of a web-based video campaign that seeks to create awareness of a humanitarian crisis cannot be measured by the number of viewers alone, it is relevant for the present discussion to comment on a video in which rapper artist MosDef enacts in a graphic and disturbing way the violence of the forced feeding procedure that the US army does to Guantanamo Bay prison Muslim detainees who are on a hunger strike. ${ }^{21}$ It was uploaded on July $8^{\text {th }}, 2013$, and 21 days after, it had gathered a little over five million views, which is a twentieth part of the public gathered by Kony 2012 in only six days. The warning at the beginning of the video may have something to do with the different size of viewership: "WARNING: some viewers may find these images distressing." That introductory sign is echoed by the advice that a CNN presenter gives before showing a part of it; it describes the intensity of human suffering represented in the almost 5 minute-long video: "Fair warning this is not an act, it is graphic and it is real!" and then she shows only a fragment of that all too realistic reconstruction of the gruesome procedure inflicted upon a hundred prisoners. ${ }^{22}$

This other example of a web-based campaign puts into perspective Madianou's (2013) critical remarks about two videos, one of which is Kony 2012, in which "suffering is surprisingly under-represented" (258). The causal link proposed by the critic between not showing enough suffering and the criticized "communitarian narcissism" of those who watched and/or participated in IC's campaign seems rather tenuous. Again, it is the dualistic principle underlying critical discourse which attributes a murky motivation to the public of one video, while, I suppose, that would not be valid for the viewers of the forced feeding enacted by MosDef in the more recent video.

There is a more specific, medium-related concept which alternates with traditional "narcissism" as a denunciation term for the soft or too comfortable (selfish?) kind of activism that is considered to be typical of enthusiasts of the IC campaign: "slacktivism." To present this notion I bring in one of the few supporters of the campaign in my media sample: "A main complaint is the oversimplification of the issues at stake coupled with a sneer about the support-

\footnotetext{
${ }^{21}$ The video is sponsored by The Guardian and it has a very concrete, explicit title: "Yasiin Bey (aka MosDef) force fed under standard Guantánamo Bay procedure." See http://www.youtube.com/watch?v=z6ACE-BBPRs , accessed on July $29^{\text {th }}, 2013$.

${ }^{22}$ The CNN presentation of this video has the title "Rapper MosDef experiences Guantanamo-style forced feeding" and can be watched at: http://www.youtube.com/watch?v=NI2LvzY_aFE, accessed on July $20^{\text {th }}, 2013$.
} 
ers' 'slacktivism"' (Baylin 2012). The argument of this journalist is based on the commonsensical notion that not everyone can be on the ground, i.e., not everyone can travel to the crisis zone to help those who are suffering there. Due to its exceptional status amidst the din of negative criticism, it is worthwhile to quote Baylin (2012) despite its length:

But is posting online about an important issue really "slacking?" If so, what would doing nothing be? Kony 2012 didn't just go viral because it simplified the issues. It appealed to the growing sense of connectedness between human beings that was first made possible by the Internet. It tapped into the common empathy of a group of people all focused on one screen, impelling them to move beyond the solitude of sitting at their computers towards telling everyone they know, and donating. This desire to act cannot be dismissed as slacktivism. In fact, it is a new and powerful type of activism, all the more so because it combines the efforts of millions of people.

It pays to contrast this minority position about the value of Kony 2012 as a tool for humanitarianism with one of the backlash texts quoted above: "You can't tweet that, but you can live by it" (Mengestu 2012). Despite the overtly positive critical purport of that statement, which is a retort to the many inaccuracies and the militarist ideology that animates Kony 2012, still the demanding option of dedicating one's life to the cause - helping to overcome the suffering of the LRA victims, contributing to their reinsertion in Ugandan society, etc. - does not seem realistic. It also has the unintended effect of placing all those who will not choose a fully committed activism in the demonized Other category of "useful idiots," to evoke an old derogatory term for the naïve collaborators of a bad cause; they are the people that Ruge (2012) describes as gullible victims of the manipulative IC campaign: "One organization set the goals and put a huge effort behind simplifying the message for mass adoption -- and that audience bit into it hook, line and sinker."

Tufekci's (2012) critical remarks on the complex series of responses or interpretants set off by Kony 2012 despite its undeniable flaws and reprehensible military objectives ("the misguided call for intervention") comes closer to a realistic semiotic account of sign action, which is the way in which meaning grows, than the calamitous vision of a mass of hypnotized followers: "This time, thanks to the emergence of a global networked public that can now talk back, a simplistic call is rapidly evolving into a multilayered discussion". I will use this view as a bridge to the next and final portion of my examination of dualism as the logical principle underlying most of the critical voices, when it came to considering the public of Kony 2012. Both narcissism or the $N N$-word and the poor result of the "Stop Kony" campaign in the streets on April $20^{\text {th }}, 2012$ will be now considered.

At this point it is fitting to bring to this discussion a researcher whose name is synonymous with the idea that today's young people - those under 35 - have the dubious honor of belonging to the most narcissistic generation in human history. The title of Jean Twenge's 2006 best-selling book says it all: "Generation Me." It is fortunate that Twenge (2013) wrote an article in which she wonders whether "social media use [is] creating or undermining beneficial social connections" (12). And it comes as no surprise, given Twenge's theory about the Generation Me, that after introducing the topic of "slackertivism," which I interpret in this context as a technological form of narcissism, she asserts that those (students) "who used Facebook more often reported more symptoms of bipolar / mania disorders, narcissism, histrionic personality disorder, and antisocial personality disorder. People high in histrionic traits and narcissism also had more friends on Facebook" (14).

Although Twenge concedes that society's trend to donate less to charity or "express empathy for outgroups" (16) existed long before social media were available, her conclusion is pessimistic: "the era of social media has not caused a reversal of these trends" (ibid.). And as an example of the social prevalence among young people of "high self-esteem or higher narcissism," Twenge mentions the "Stop Kony" campaign. She finds fault with its very disappointing culmination, the "Cover the night" event, which was planned to take place on the night of April 20, 2012, when activists would hang thousands of posters with Joseph Kony's face in cities of North America: "Sure enough, when the April 20 'day of action' named in the 
video arrived, few posters were used and even fewer people actually protested" (17). Based on that disappointing result, Twenge (2013) reaches a melancholy conclusion: "We get the social movements we deserve. Social media are powerful tools for raising awareness and spreading the word for social action, political involvement, and protests. But if young citizens initially have little interest in these issues [...] then they are unlikely to use social media for these purposes. Social media do boost positive self-views. This boost may have some benefits for self-esteem, but may lead to negative interactions with others if the boost also raises narcissism" (17).

It is strange, however, that this scholar does not mention in her article an episode which critics of the IC campaign find necessary to include in the discussion of Kony 2012 when it comes to evaluating it after March $15^{\text {th }}, 2012$ : the so-called public and shameful "meltdown" of the co-founder and visible protagonist of the video on that day. ${ }^{23}$ Even if it is reasonable to describe the offline outcome of "Stop Kony" as very disappointing, it is relevant to mention that between that day and the accumulation of the massive number of viewers of the video, the backlash took place. And part of it was the much commented disgraceful exposure of Jason Russell, who was recorded running naked and apparently drugged in broad daylight. Far from leading to the diagnosis of social media "boost(ing) self-views" or "rais(ing) narcissism," as Twenge claims, the poor result could point to the opposite conclusion, namely, an increased awareness of the risks of a massive web-based video campaign.

It is also important to mention that Arnett (2013), a respected scholar in the field of the psychology of adolescence, makes a cogent case against Twenge's narcissism thesis by offering different interpretations of her recent data (Twenge 2013a). As a contrast with what many critics of the backlash to Kony 2012 state regarding the psychological condition of its viewers, I will quote Arnett's (2013) conclusion about the diagnosis of blatant narcissism of young people today, which is Twenge's $(2006,2013 a)$ thesis, an attitude which shows through, she writes, even in their use of social media for a humanitarian campaign:

The other step that can be taken for the benefit of emerging adults is to stop promoting negative stereotypes about them, that they are selfish, lazy, and worse than ever. These false claims are harmful, not only because they are false and therefore unfair but because they discourage adult society from supporting the programs that would give emerging adults a broader range of opportunities for education, work, and service. It is time to retire the damaging and false stereotypes and instead celebrate today's emerging adults for the extraordinary generation they are. (Arnett 2013, 9)

Could it be that dualism, the mode of analysis that is most antagonistic to synechism, according to Peirce, is at the basis of this very negative view of the audience of the IC video? And could the negative bias against the epistemic value of images, of iconic signs, partly account for the harsh condemnation of Kony 2012? Far from minimizing the many inaccuracies, the militaristic ideology and the suppression of the voices of the Other in this video campaign, I want to call attention to the involuntary reproduction of the main critical objection and accusation against it. To condemn the audience of Kony 2012 and to account for their interest and commitment to the campaign on the basis of the alleged narcissism of its members is a gross oversimplification akin to oversimplifying the intricate geopolitical situation in Africa.

\section{A Synechistic Based Semiotic Approach to Critical Visual Discourse}

A way to overcome the analytical and critical impasse described above may be found in Braga's $(2006,21-44)$ notion of "the response system," which complements the concepts of

\footnotetext{
${ }^{23}$ Many of the accounts of this episode include in their title the phrase "Kony 2012." They describe the public collapse of Jason Russell, on April 15, 2012, when he was caught in camera running naked and making incoherent and rather obscene gestures: "Kony 2012 Director Arrested for Masturbating in Public" http://www.youtube.com/watch?v=NmUs0jh3264, "Kony 2012: Jason Russell Naked Meltdown" (http://www.youtube.com/watch?v=ATRel6Qm230). This is also predictably true of some of the parodic memes of that heavily viewed incident: “Jason Biggs Mocks 'Kony 2012' Director in Naked Meltdown Video" http://www.youtube.com/watch?v=H4aWgX4LYZO .
} 
sender and receiver of media theory. His analytical proposal holds that "In this kind of circulation that interests us we will find out what society does with its media: it is therefore a response" (29). Thus we can relinquish the dyadic pair of "active" to refer to the influence of mass media, and "passive" to indicate social behaviour regarding the media. The latter, writes Braga (2006, 29), would no longer be construed as consisting of "simply receive and choose" because the media public "generates a dynamical work, namely, responses." His proposal is akin to Peirce's triadic theory of sign action, to the generation of interpretants, though we must remember that the three components of the sign constitute "a tri-relative influence not being in any way resolvable into actions between pairs" (EP 2:411). To approach the social impact of Kony 2012 semiotically is an alternative to viewing the matter in dualistic, Manichean terms. Dualism in critical discourse cannot help but reintroduce the distorting oversimplification that is at the roots of some of the accusations made regarding the public of the IC video and its visual rhetoric. The principle of logical continuity that governs the link between reality and its evolving, fallible representations or synechism is the epistemological alternative proposed here.

The critical condemnation of the millions of viewers of Kony 2012 in harsh terms that include what I proposed calling "the NN-word" takes us back to the year 1948, when pioneers of the communication field posited the existence of a non- or anti-function to preserve their quasi-biological model of the influence of mass media on society. Just as the latent "narcotizing dysfunction" served Lazarsfeld and Merton to appease their uneasiness about what they thought should have become a better society, where more abundant, widespread, cheap information would help people to become more active democratic citizens, the voices of the critical backlash to Kony 2012 construe its Gargantuan audience that not only watches the long video on YouTube but also contributes to that campaign with donations, time, energy, enthusiasm, as a zombie-like army of ignorant, self-satisfied narcissists.

A typical criticism of the public's awareness of that humanitarian crisis in Africa - despite the many flaws that were denounced loudly and directly after the "Stop Kony" campaign was launched by the critics - is that there is no constructive link between this incomplete, flawed knowledge about the child soldiers and other victims of the LRA and the taking of any kind of beneficial action regarding it. It is inevitable to wonder about the almost unanimous sweeping doubt and suspicion about the effect of these persuasive images. Could this be another upshot of "the curmudgeon spirit" (Ransdell, in Andacht 2003) characteristic of modernity, of the iconophobic reflex that ascribes genuine knowledge only to symbols and mistrusts iconic signs? To raise these questions in connection with the stirring debate that arose about the impact of a humanitarian campaign that had a wonderful, horrible life cycle, such as Kony 2012, is necessary, if we are to heed the risks of oversimplifying and distorting reality through our signs, whether they be iconic, indexical or symbolic.

What I have described above is a critical operation based on Peirce's triadic semiotic model, whose critique of all forms of reductionistic dualism is still valid today, if we want to find out how mediation affects our lives. Just as the critics of Kony 2012 helped us understand that attractive images, persuasive words, and a deceivingly simple solution to a complex humanitarian crisis could cause more harm than good to those in need, despite good intentions, a semiotic analysis of that critical discourse can make us aware of the blind spots or contradictions that weaken the critiques by distorting the complex reality of the world of sign action. Such criticism inflicts its own kind of reductionism regarding a key component of the mechanism of sign action, namely, the autonomous work of the interpretants. They are the semiotic effects that it is the logical purport of signs to generate, the way in which they grow in complexity along with the evolving reality they represent.

The aim of this paper was to understand what is involved in interpreting visual signs such as those used in the video of a web-based humanitarian campaign, the images created and distributed by the NGO Invisible Children in March 2012. For this goal, I revisited the classical dichotomy of the active vs. passive roles discussed in the field of communication studies since late $19^{\text {th }}$ century up to the present regarding the much feared media influence. The case study of the controversial Kony 2012 campaign has served to revisit the too easily tak- 
en for granted notion of "audience" (Mosco and Kaye 2000) and to consider the relevance of the early functionalist concept of "narcotizing dysfunction" (Lazarsfeld and Merton 1948).

My proposal is that a possible way to overcome the shortcomings and inconsistencies inherent in these traditional notions is to adopt Peirce's triadic semiotic as a theoretical and methodological framework; it consists in a tri-relative logical relationship of an object, a representamen or sign and an interpretant, whose generation is the systemic purpose of the three-term relationship. One of its contributions is to avoid the pitfalls that stem from reductionism in the critical discourse of visual media, which is the consequence of its underlying dualism, a mode of thought that cannot help but reproduce what is found to be most objectionable in the video of Invisible Children. Just as it is easy to realize that there is gross oversimplification of geopolitical complexities, melodramatic demonization and suppression of the voices of the victims and real protagonists of the kidnapped child soldiers crisis of East and Central Africa in the audiovisual representation of the IC video, a similar objectionable rhetorical and ideological strategy is at work in demonizing the public of Kony 2012, which is recurrent in many voices of the critical backlash to it. The semiotic approach envisages critically a situation in which there is far more than an inevitably dumbed down, non-critical or nonreflective understanding of the world that is represented in this audiovisual narrative and watched by so many in the social media and video websites such as YouTube.

But what if meaning is a far more complex process than the indoctrination mechanism that can be inferred from many of the critiques and denunciations made of the effects on the audience of Kony 2012? What would be the consequence of Peirce's often quoted claim that "Symbols grow. They come into being by development out of other signs. [...] So it is only out of symbols that a new symbol can grow" (EP2: 10). Such logical growth, I claim, can be observed in the ample discourse that began directly after the video that denounced the criminal deeds of a rebellious group in Africa was uploaded and watched by millions. Despite the inaccuracies and the dangerous militarist ideology sponsored by the video of IC, there is nothing intrinsically deleterious or corrupting in the images, which it is the logical mission of symbols to spread, for us to make sense of the world. The wealth of opinions, of detailed information, of counter-ideological assertions, both in written and visual media that was set off at a stunning rate by Kony 2012 and by the "Stop Kony" campaign do not justify the dark, pessimistic views on an allegedly passive, inert audience that was misled by this new-fangled Pied Piper of neo-humanitarian devious ways. Far from that being the case, the poor outcome of the final phase of the campaign, which was supposed to take place in the streets of the world to make Joseph Kony famous, reveals a potential effect of raised awareness in the public regarding the complexities of the world and its crises. That is precisely the work of the interpretants that evolve as reality reveals more aspects along time, and that is why this analytical component should be part of contemporary critical theory of visual media.

\section{References}

Andacht, Fernando. 2010. On the Media Representation of Reality: Peirce and Auerbach, Two UnlikeIy Visitors of the House of Big Brother. In Trans-Reality Peeping Around the Corner: Metaperspectives on Reality Television, edited by Sophia Van Bauwel and Nico Carpentier, 37-64. Totowa, NJ: Rowman \& Littlefield.

Andacht, Fernando. 2003. Iconicity Revisited. An Interview with Joseph Ransdell. Recherches Sémiotiques-Semiotic Inquiry 23 (1-2-3): 221-240.

Arnett, Jeffrey. 2013. The Evidence for Generation We and Against Generation Me. Emerging Adulthood 1(1): 5-10.

Baran, Stanley J. and Denis K. Davis. 2009. Mass Communication Theory. Foundations, Ferment and Future. Boston: Wadsworth, Cengage Learning.

Blattman, Chris. 2012. My Thoughts on Kony 2012 (and a Defense of Invisible Children?) Blog of Chris Blattman. March 10. Accessed March 14, 2012. chrisblattman.com/2012/03/10/my-thoughtson-kony-2012-and-a-defense-of-invisible-children/ .

Boltanski, Luc. 2004. Distant Suffering Morality, Media and Politics. Translated by Graham Burchell. Cambridge: Cambridge University Press. 
Braga, José Luiz. 2006. A sociedade enfrenta sua mídia. Dispositivos sociais de crítica midiática. São Paulo: Paulus.

Brown, Barbara et al. 2012. React and Respond: The Phenomenon of Kony 2012. Written on behalf of the Outreach Council of the African Studies Association. UCLA. African Studies Center. Accessed May 20, 2012, http://www.international.ucla.edu/article.asp?parentid=125256.

Butcher, Bill. 2012. It's a Kony Game. Author's Blog. March 15. Accessed May 10, 2012. http://billpurkayastha.blogspot.com/2012/03/its-kony-game.html .

Carroll, Rory. 2012. Kony 2012 Cover the Night Fails to Move from the Internet to the Streets. April 21. The Guardian. Accessed April 25, 2012, http://www.theguardian.com/world/2012/apr/21/kony2012-campaign-uganda-warlord .

Castells, Manuel and Amelie Arsenault. 2006. Conquering the Minds, Conquering Iraq. The Social Production of Misinformation in the United States - A Case Study. Information, Communication \& Society 9 (3): 284-307.

Chouliaraki, Lilie. 2012. The Theatricality of Humanitarianism: A Critique of Celebrity Advocacy. Communication and Critical / Cultural Studies 9 (1): 1-21.

Cole, Teju. 2012. The White Savior Industrial Complex. The Atlantic, March 21. Accessed April 10, 2012. http://www.theatlantic.com/international/archive/2012/03/the-white-savior-industrialcomplex/254843/.

Cronin-Furman, Kate and Amanda Taub. 2012. Who is the Hero? New York Times, March 9. Accessed March 12, 2012. http://www.nytimes.com/roomfordebate/2012/03/09/kony-2012-and-thepotential-of-social-media-activism/in-kony-2012-who-is-the-audience-and-who-is-the-hero .

Curtis, Polly and Tom McCarthy. 2012. Kony 2012: What Happens Next? The Guardian, April 20. Accessed April 25, 2012. http://www.theguardian.com/politics/reality-check-with-pollycurtis/2012/apr/20/kony-2012-what-happens-next .

Edmondson, Laura (2012). Uganda Is Too Sexy: Reflections on Kony 2012. The Drama Review 56 (3): 10-17.

Finnegan, Amy C. (2013). Beneath Kony 2012: Americans Aligning with Arms and Aiding Others. AfricaToday 59 (3): 136-16.

Goodman, J. David. 2012. Backlash Aside, Charities See Lessons in a Web Video. March 16. New York Times. Accessed April, 10, 2012. http://www.nytimes.com/2012/03/16/us/backlash-asidecharities-see-lessons-in-a-web-video.html .

Goodman, J. David and Jennifer Preston. 2012. How the Kony Video Went Viral. March 9. New York Times. Accessed April 10, 2012. http://thelede.blogs.nytimes.com/2012/03/09/how-the-kony-videowent-viral/.

Greenblatt, Alan. 2012. The Social Media Shuffle: From Kony To Spooning. April 19. National Public Radio. Accessed April 24, 2012. http://www.npr.org/2012/04/19/150964208/young-people-turnfrom-kony-to-spooning-record .

Gregory, Sam (2012). Kony 2012 through a Prism of Video Advocacy Practices and Trends. Journal of Human Rights Practice 4 (3): 463-468.

Halpin, Mikki. 2012. Start With Listening, Not Talking. New York Times. Room for debate, 10.03.2012 Accessed April 12, 2012. http://www.nytimes.com/roomfordebate/2012/03/09/kony-2012-and-thepotential-of-social-media-activism/activism-starts-with-listening .

Huyssens, Andreas. 1986. Mass Culture as Woman. In Studies in Entertainment: Critical Approaches to Mass Culture, edited by Tania Modleski,188-207. Bloomington, IN: Indiana University Press.

Invisible Children. 2012a. KONY 2012. YouTube video, 29:59, posted by invisiblechildreninc, March 5. Accessed March 7, 2012. http://www.youtube.com/watch?v=Y4MnpzG5Sqc .

Invisible Children. 2012b. Jason Russell 'Wow. Thank you' speech KONY 2012. March 8. Accessed March 15, 2012. http://www.youtube.com/watch?v=3IPZkDD1Byo .

Invisible Children. 2012b. Kony 2012, Part II: Beyond Famous. YouTube video, 19:48, posted by invisiblechildreninc, April 5. http://www.youtube.com/watch?v=c_Ue6REkeTA Accessed April 10, 2012.

Izama, Angelo. 2012. Acholi Street. Stop \#Kony2012. Invisible Children's Campaign of Infamy. Author's blog. March 7. Accessed March 16, 2012. http://angeloizama.com/2012/03/07/acholi-streetstop-kony2012-invisible-childrens-campaign-of-infamyl .

Izama, Angelo. 2012a. A Flawed Call to Action. New York Times. Room for Debate. March 10th. Accessed April 12, 2012. http://www.nytimes.com/roomfordebate/2012/03/09/kony-2012-and-thepotential-of-social-media-activism/a-flawed-call-to-action .

Izama, Angelo. 2012b. Kony is not the Problem. March 20. New York Times. Accessed March 25, 2012. http://www.nytimes.com/2012/03/21/opinion/in-uganda-kony-is-not-the-only-problem.html. 
Jenkins, Henry. 2009. If It Doesn't Spread, It's Dead (Part One): Media Viruses and Memes. Author's blog. February 11. http://henryjenkins.org/2009/02/if_it_doesnt_spread_its_dead_p.html. Accessed June 10, 2013.

Jenkins, Henry. 2009a. If It Doesn't Spread, It's Dead (Part Two): Media Viruses and M Sticky and Spreadable - Two Paradigms. Author's blog. February 13. Accessed June 10, 2013. http://henryjenkins.org/2009/02/if_it_doesnt_spread_its_dead_p_1.html.

Jerabek, Hynek. 2011. Merton and Lazarsfeld: Collaboration on Communication Research: Two Papers, Two Research Instruments, and Two Kindred Concepts. Sociologický časopis 47 (6): 11911214.

Jones, Pete. 2012. Kony 2012: Invisible Children prepares Cover the Night stunt amid criticism. The Guardian. April 20. Accessed April 24, 2012. http://www.theguardian.com/world/2012/apr/20/kony2012-cover-night-campaign .

Kagumire, Rosebell. 2012. "My Response to Kony 2012." March 7. Accessed April 4, 2012. http://rosebellkagumire.com/2012/03/08/kony2012-my-response-to-invisible-childrens-campaign/ .

Kingwell, Mark. 2002. Practical Judgments. Essays in Culture, Politics, and Interpretation. Toronto: University of Toronto Press.

Lazarsfeld, Paul and Robert Merton. 1948. Mass Communication, Popular Taste, and Organized Social Action. In The Communication of Ideas, edited by Lyman Bryson, 95-118. New York, NY: Harper \& Brothers.

Liszka, James. 1996. A General Introduction to the Semeiotic of Charles S. Peirce. Bloomington, IN: Indiana University Press.

Levin, Anthony. 2013. Making the Invisible Visible: Photographic Trials in Neil Abramson's Soldier Child. Research in African Literatures 44 (2): 105-124.

Madianou, Mirca. 2013. Humanitarian Campaigns in Social Media. Network Architectures and Polymedia events. Journalism Studies 14 (2): 249-266.

Mamdani, Mahmood. 2012. What Jason Didn't Tell Gavin and Other Critiques of Invisible Children. The Monitor, March13. Accessed March 30, 2012. http://www.monitor.co.ug/artsculture/Reviews//691232/1365090/-/c8l08/-/index.html .

Margon, Sarah. 2012. Awareness Can Translate Into Action. New York Times. Room for Debate. March 10. Accessed April 9, 2012. http://www.nytimes.com/roomfordebate/2012/03/09/kony-2012and-the-potential-of-social-media-activism/awareness-can-translate-into-action .

Mengestu, Dinaw. 2012. Not a Click Away: Joseph Kony in the Real World. Warscapes Blog, March 12. Accessed April 8, 2012.http://www.warscapes.com/reportage/not-click-away-joseph-kony-realworld.

Mosco, Vincent and Lewis Kaye. 2000. Questioning the Concept of Audience. In Consuming Audiences. Production and Reception in Media Research, edited by Ingunn Hagen and Janet Wasko, 3146, Cresskill, N.J.: Hampton Press.

Nothias, Toussaint. 2013. 'It's Struck a Chord we Have Never Managed to Strike': Frames, Perspectives and Remediation Strategies in the International News Coverage of Kony 2012. African Journalism Studies 34 (1): 123-29.

Peirce, Charles Sanders. 1931-58. The Collected Papers of Charles S. Peirce. Vols. I-VI, edited by Charles Hartshorne and Paul Weiss. Vols. VII-VIII, edited by Arthur Burks. Cambridge, MA: Harvard University Press.

Peirce, Charles Sanders. 1998. The Essential Peirce: Selected Philosophical Writings, v. 2 (18931913), edited by the Peirce Edition Project. Bloomington, IN: Indiana University Press.

Ransdell, Joseph. 1997/1986. On Peirce's Conception of the Iconic Sign. In Iconicity. Essays on the Nature of Culture. Paul Bouissac et al. (eds.). Tübingen: Stauffenburg, 51-74. (Citations of this text refer to the revised version of it made by the author in 1997, available in Arisbe. The Peirce Gateway. http://www.cspeirce.com/menu/library/aboutcsp/ransdell/iconic.htm . Accessed August 10, 2012.

Ransdell, Joseph. 1979. The Epistemic Function of Iconicity in Perception. Peirce Studies (Institute for Studies in Pragmaticism) 1: 51-66.

Ruge, TMS. 2012. Kony 2012 Is Not a Revolution. New York Times. Room for Debate, March 10. Room for Debate, March 10. http://www.nytimes.com/roomfordebate/2012/03/09/kony-2012-andthe-potential-of-social-media-activism/kony-2012-is-not-a-revolution. Accessed April 12, 2012.

Santaella, Lucia and Winfried Nöth. 2004. Comunicação e semiótica. São Paulo: Hacker.

Shannon, Lisa. 2012. Kony's Victims and the Kony 2012 Video. March 9. Accessed March 13, 2012. http://kristof.blogs.nytimes.com/2012/03/09/konys-victims-and-the-kony-2012-video/? r $r=0$. 
Shannon, Lisa. 2012a. Translating Awareness into Results. New York Times. Room for Debate, March 10. Accessed on March 14, 2012. http://www.nytimes.com/roomfordebate/2012/03/09/kony2012-and-the-potential-of-social-media-activism/translating-awareness-into-results .

Shaughnessy, Haydn. 2012. Kony 2012: Successes and Failings in the "Stop Kony Campaign." Forbes, March 11. http://www.forbes.com/sites/haydnshaughnessy/2012/03/11/kony-2012successes-and-failings-in-the-stop-kony-campaign/. Accessed November 15, 2012.

Tufekci, Zeinep. 2012. The Value of a Global Discussion. New York Times. Room for Debate, March 10. Accessed March 14, 2012. http://www.nytimes.com/roomfordebate/2012/03/09/kony-2012-andthe-potential-of-social-media-activism/kony-2012-and-the-value-of-a-global-discussion .

Twenge, Jean. 2013. Does Online Social Media Lead to Social Connection or Social Disconnection? Journal of College and Character 14 (1): 11-20.

Twenge, Jean. 2013a. The Evidence for Generation Me and Against Generation We. Emerging Adulthood 1:1, 11-16.

Twenge, Jean. 2006. Generation Me: Why Today's Young Americans Are More Confident, Assertive, Entitled - and More Miserable Than Ever Before. New York, NY: Free Press.

Visible Measures Blog. 2012. Update: Kony Social Video Campaign Tops 100 Million Views March 12. Accessed March 15, 2012. http://www.visiblemeasures.com/2012/03/12/update-kony-social-videocampaign-tops-100-million-views/.

\section{About the Author}

\section{Fernando Andacht}

is a Full Professor of the Department of Communication, University of Ottawa, visiting Professor of the Graduate Program in Communication of the Universidade Tuiuti do Paraná. He does research on the representation of reality in audiovisual media from a semiotic perspective. He was a researcher of the Centro Nacional de Pesquisa (2005-2007) and at present of the Social Sciences and Humanities Council (2010-2013). Recent publications: ¿Qué puede aportar la semiótica triádica al estudio de la comunicación mediática? (2013); The dance of identification: the signs of the self in the age of Reality Television (2012); Embodied witnessing: on the use of indexical mimesis in a documentary film (2011); On the media representation of reality: Peirce and Auerbach, two unlikely visitors of the house of Big Brother (2010); Reflections on iconic celebrity: ... such stuff as dreams are made on (2010). 